\title{
The Thermal Performance of Traditional Residential Buildings in Kathmandu Valley
}

\author{
Sushil B. Bajracharya \\ Department of Architecture and Urban Planning, Central Campus, Pulchowk, IOE, TU, Lalitpur, Nepal
}

Corresponding Email: sushil_bajracharya@hotmail.com

\begin{abstract}
This paper seeks to investigate into the aspects of thermal performance of traditional residential buildings in traditional settlements of Kathmandu valley. This study proceeds to analyze the detailed field data collected, with a view to identify the indoor thermal environment with respect to outdoor thermal environment in different seasons. This paper also compares the thermal performance of traditional buildings with modern residential buildings of traditional settlements of the valley. There is a regression analysis to obtain information about the thermal environment of different traditional and modern residential buildings with different conditions. The paper concludes that, thermal performance of traditional residential building, adapted in various ways to the changing thermal regime for thermal comfort is better than that of contemporary buildings.
\end{abstract}

Keywords: Traditional, Modern, Residential building, Indoor, Outdoor, Air temperature

\section{Introduction}

It is understood that every traditional building perform better thermal environment than contemporary buildings. There were many researches generally speaking, the thermal performance of traditional dwellings is better than that of modern dwellings $[1,3,8,10]$. However, a quantitative analysis is necessary to give the information needed to prove better thermal comfort. A qualitative understanding can easily be formed from the information. But no such study can be found in Nepal and world, so this paper focused on the measurement of thermal performance, energy efficiency and environment saving with field experiments.

There is a general perception that traditional architecture is better in terms of thermal environment than contemporary architecture [12]. The present study has been set out to investigate thermal environment of traditional residential buildings in traditional settlement of Kathmandu valley in Nepal. The study also compares the thermal environment of the contemporary residential building with traditional buildings of Kathmandu. This study clarifies the thermal performance of the traditional and modern residential building in a composite climate of Kathmandu.

As Madhavi [7] study calls for a code of practice balancing modernization with the vernacular in Marikal town, Andhra Pradesh of India, somehow our study also similar to call for a code of practice balancing modernization with the vernacular architecture in Kathmandu in future. The study aims to examine how the traditional houses of Kathmandu may inform thermal comfort for future with the same materials, building forms and construction technology. One of purposes of this paper is to help to stop the degradation of traditional architecture from cityscape of 
Kathmandu. Another main purpose is to help for conservation of this architecture with its materials, technology and form in future.

This study has following objectives:

1. To evaluate thermal performance of traditional houses

2. To compare thermal performance of traditional houses with modern houses

3. To develop new equation to predict the indoor thermal environment with the help of outdoor temperature

\section{Methodology}

\subsection{Investigated area}

The study area is traditional and modern residential buildings located in old urban settlement of Kathmandu valley. In order to fulfill the objective, the present paper has adopted quantitative method which was carried out intensively in field. In this sense, the main research focuses to field study with monitoring thermal performance of different residences for a year. The field experimental research carried out in Patan and Kirtipur of the Kathmandu valley. The evaluation of thermal environment of buildings contains with field data, sample analysis, regression analysis, followed by discussion and aiming to draw the results and conclusions. The detail methodology of this study was explained below. All the data collected from field was analyzed statistically with the help of SPSS software.

\subsection{Investigated buildings}

The basic traditional residential building of Kathmandu valley was designed with vertical spatial planning around a courtyard or street (Fig.1). The building plan covers nearly 54 square metres land which is very less compared to modern practice in Kathmandu. So this type of house has to be vertically oriented as said by Korn. Security considerations and the need to use as little irrigable land for building purposes caused the Newari house to be vertically oriented [6]. The house consists of three to four storeys with utility rooms in heavy ground floor (Chheli). The bed rooms are located in first floor (Chotan). The living room is located in second floor (Matan) and kitchen, dining, puja and store in attic (Baiga).

The traditional architecture of the valley developed with mud architecture as in most of part of ancient architecture of the world. The major building material is sundried brick, burnt brick, mud mortar, mud plaster, clay tile, timber and stone. The thick load bearing wall of 450 to $600 \mathrm{~mm}$ built with multilayer of Burnt Red brick (pakki apa), Sun dried brick (kachi apa) and mud plaster placed from outside to inside in external walls. One layer of burnt bricks are used to exposed for weather resistance where as sun dried bricks are use in 3/4 part of wall in inner side. Mostly the central load bearing wall consists of $450 \mathrm{~mm}$ built with only Sun dried brick ( $k a c h i$ apa) and mud plaster.

The fourteen numbers of different traditional residences listed as research sample randomly with photographs and drawings. This paper focuses randomly selected only five residences among these residences for detail study for evaluation of thermal environment with measurement of temperature data. Also two modern residences were selected for detail study with measurement of temperature data to compare with traditional buildings (Table 1). 
Table 1: Description of the investigated residential buildings

\begin{tabular}{|c|l|c|c|c|c|c|c|c|c|}
\hline S.No. & House & Type & Location & Area & Lay out & Orientation & Construction & Planning & Roof \\
\hline 1 & D B Maharjan & Traditional & Dev Dhoka & Kirtipur & Street & South & Loadbearing & Vertical & Slope \\
\hline 2 & A M aharjan & Traditional & Yelmul & Patan & Courty ard & South & Loadbearing & Vertical & Slope \\
\hline 3 & S M aharjan & Traditional & Subahal & Patan & Street & North & Loadbearing & Vertical & Slope \\
\hline 4 & N D Maharjan & Traditional & Dupat & Patan & Courty ard & North & Loadbearing & Vertical & Slope \\
\hline 5 & N L Maharjan & Traditional & Pilanchhe & Patan & Courty ard & East & Loadbearing & Vertical & Slope \\
\hline 6 & P Tandukar & Modern & Konti & Patan & Street & East & Frame & Not Vertical & Flat \\
\hline 7 & R M Shrestha & Modern & Kobahal & Patan & Courty ard & West & Frame & Not Vertical & Flat \\
\hline
\end{tabular}
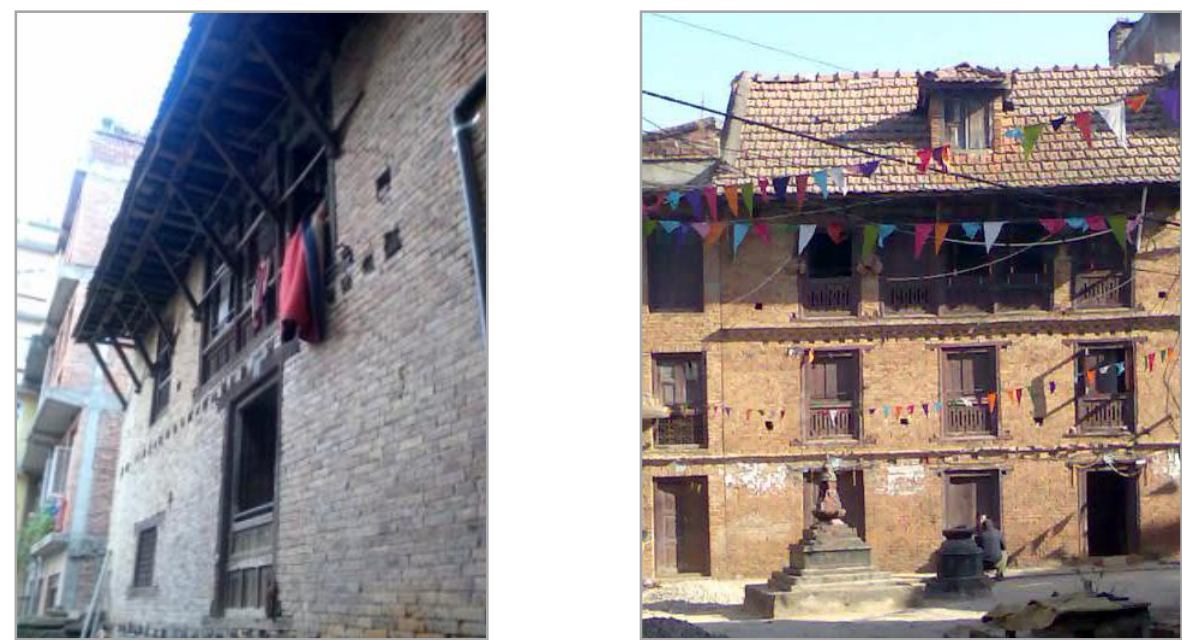

Figure 1: Sample of investigated traditional residential buildings in Kathmandu

\subsection{Measurement of air temperature}
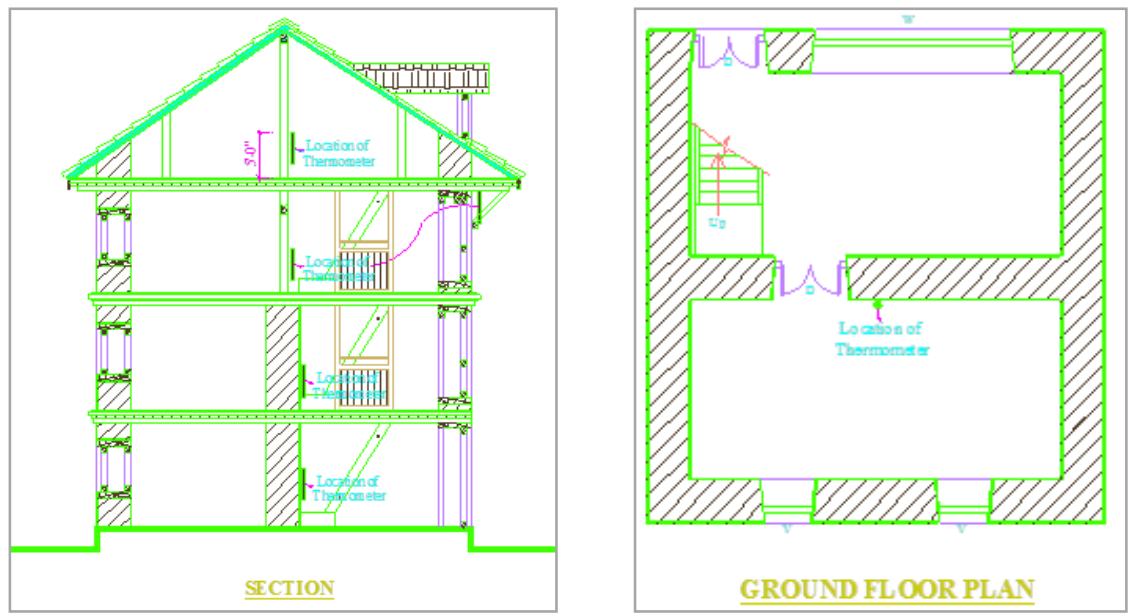

Figure 2: Plan and section with locations of wall thermometers inside and outside of the building 
The investigations of thermal environment of the building were conducted by measuring air temperature in summer, autumn, winter and spring seasons. The air temperatures were measured for normally thirty days in each season. There were five measurement points in each building. The four points were inside from ground floor to top floor. The indoor measurement points were $150 \mathrm{~cm}$ above the each floor level. The one point was located outside the living room in third floor below the roof overhang to know outdoor air temperature. The outdoor measurement point was nearly $30 \mathrm{~cm}$ below the roof level. Care was taken to avoid direct sunlight on the thermometer throughout the day. All data were measured three times a day in each season by simple room thermometers (Omsons ISO 9001:2000 Company) manually. All data were measured seven o'clock in the morning, two o'clock in the afternoon and ten o'clock in the evening of each day. The measured data were calibrated. There were nearly 11700 temperature data collected in five spaces of seven houses in one year.

\subsection{Climate of Kathmandu valley}

The study of indoor thermal environment of the building directly depends on outdoor air temperature in different seasons and climate of Kathmandu valley. In order to study indoor thermal environment, this paper focused to investigate climate of the valley.

Table 2: Climatic data of Kathmandu

(Source: Meteorological Department, Government of Nepal)

\begin{tabular}{|c|c|c|}
\hline 1 & Climatic feature & Composite climate \\
\hline 2 & Landscape & Relatively flat \\
\hline 3 & Vegetation & Abundant vegetation \\
\hline \multirow[t]{2}{*}{4} & Solar radiation & Intense in summer \& \\
\hline & & Diffused in monsoon \\
\hline \multirow[t]{4}{*}{5} & Ambient temperature: & \\
\hline & $\begin{array}{l}\text { Summer } \\
\text { Night }\end{array}$ & $\begin{array}{l}\text { mean maximum } 30^{\circ} \mathrm{C} \\
\text { mean minimum } 20^{\circ} \mathrm{C}\end{array}$ \\
\hline & $\begin{array}{l}\text { Winter } \\
\text { Night }\end{array}$ & $\begin{array}{ll}\text { Day } & \text { mean maximum } 19^{\circ} \mathrm{C} \\
& \text { mean minimum } 3^{\circ} \mathrm{C}\end{array}$ \\
\hline & Diurnal variation & $>10^{\circ} \mathrm{C}$ \\
\hline \multirow[t]{2}{*}{6} & Relative humidity & $78 \%$ (Monsoon) \\
\hline & & $\& 50-60 \%$ (Summer \& Winter) \\
\hline 7 & Precipitation & $>1000 \mathrm{~mm}$ per year \\
\hline 8 & Winds & Variable \\
\hline 9 & Sky conditions & Clear sky (Summer) \& Generally overcast (Monsoon) \\
\hline
\end{tabular}

Kathmandu lies in subtropical region but due to altitude nearly 1200 metre above sea level, it has composite climate. Generally, it is divided into four seasons: winter, summer, autumn and spring. But the Kathmandu's climate has three distinct seasons, i.e. cool dry, hot dry and warm wet seasons [11]. The cool dry season lasts from November to March. December, January and February are the coldest months. It is characterized by low temperature of about mean minimum 
of $3^{\circ} \mathrm{C}$ during night (Table 2). The climate of Kathmandu is generally dry and hot in May and June.

The summer months have a mean maximum air temperature is about $30^{\circ} \mathrm{C}$ and minimum is about $20^{\circ} \mathrm{C}$. The main feature of this season is hot days and warm nights. Generally monsoon season is warm wet and it lasts from June to August months. The total rainfall is more than 1000 $\mathrm{mm}$ in a year. But ninety percent of rainfall occurs only during monsoon season.

\section{Results}

\subsection{Mean Comfort Temperature}

The Nicol graph [9] starts from findings that the temperature which people finds comfortable indoors varies with the mean outdoor temperature for free running building (not mechanically heated or cooled). According to Nicol, the 'adaptive comfort temperature' is the temperature which people finds comfortable in a given situation. Figure 3 shows an example for monthly mean temperature of Kathmandu and compares indoor comfort temperature of Nicol graph and [10]. The relationship between indoor comfort temperature and outdoor temperature can be used to compare for buildings of Kathmandu. The lowest temperature considered comfortable might be nearly $18^{\circ} \mathrm{C}$ during winter and highest to $26^{\circ} \mathrm{C}$ in summer from Nicol graph and nearly $15^{\circ} \mathrm{C}$ during winter and highest to $26^{\circ} \mathrm{C}$ in summer from Rijal et al. (2010). According to [10, $13^{\circ} \mathrm{C}$ is indoor comfort zone temperature during winter for Kathmandu valley (Table 3).

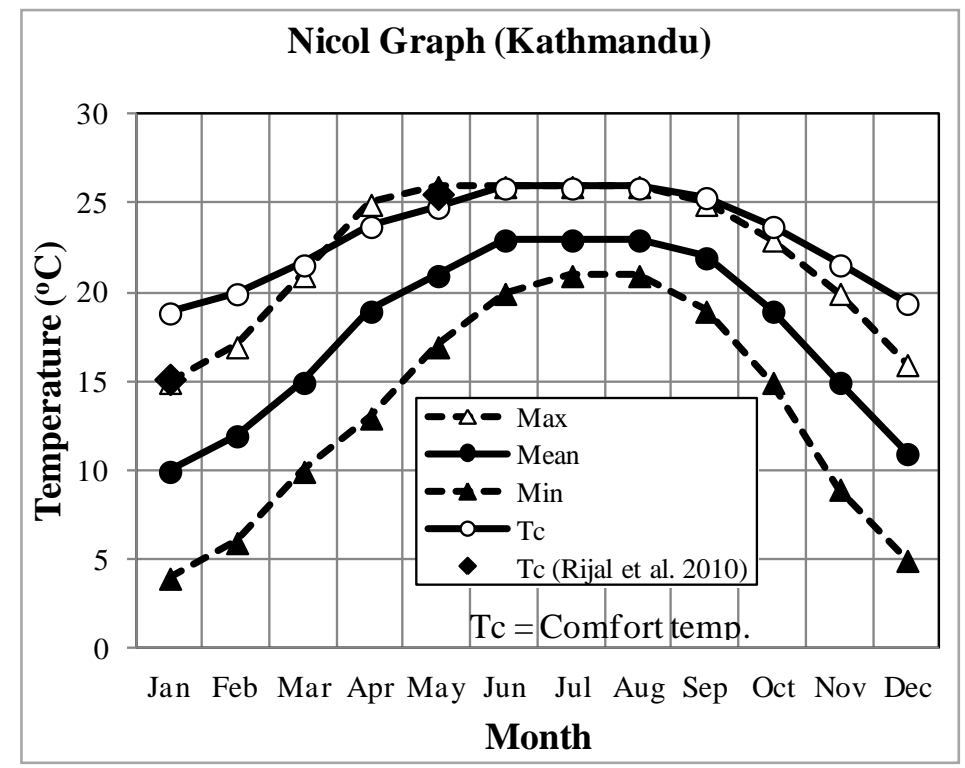

Figure 3: Outdoor air temperatures and the comfort temperature $\left(\mathrm{T}_{\mathrm{c}}\right)$ for residential buildings of Kathmandu, Nepal (source: [9] \& [10]) 
Table 3: Adaptive Indoor Comfort Temperatures and Comfort Zone from Nicol and Rijal comfort temperature $\left(\mathrm{T}_{\mathrm{c}}\right)$ in summer and winter for Kathmandu

\begin{tabular}{|c|c|c|c|c|c|c|c|c|}
\hline S.No. & Thermal & Thermal & Nicol & Tc $\left({ }_{0} \mathrm{C}\right)$ & Rijal & Tc (oC) & Comfort & Remarks \\
\hline & Sensation & Scale & Summer & Winter & Summer & Winter & Category & \\
\hline 1 & Hot & 3 & 32 & * & 32 & * & Very Uncomfortable & \\
\hline 2 & Warm & 2 & 30 & * & 30 & * & Uncomfortable & \\
\hline 3 & Slightly Warm & 1 & 28 & * & 28 & * & Comfortable & \multirow{3}{*}{$\begin{array}{c}\text { Comfort } \\
\text { Zone }\end{array}$} \\
\hline 4 & Neutral & $\mathbf{0}$ & 26 & 19 & 26 & 15 & Very Comfortable & \\
\hline 5 & Slightly Cool & -1 & * & 17 & * & 13 & Comfortable & \\
\hline 6 & Cool & -2 & * & 15 & * & 11 & Uncomfortable & \\
\hline 7 & Cold & -3 & * & 13 & * & 9 & Very Uncomfortable & \\
\hline
\end{tabular}

\subsection{Indoor and outdoor air temperature of traditional building}

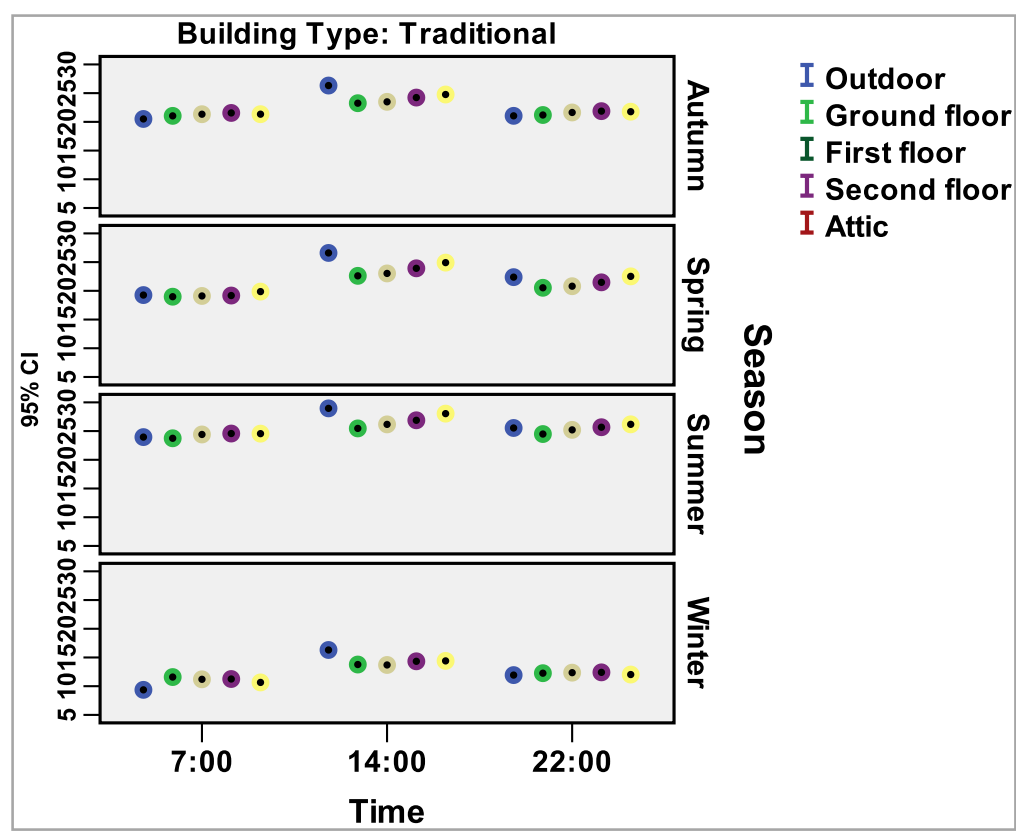

Figure 4: Mean Indoor and outdoor air temperature with 95\% confidence interval in traditional residential buildings during different time and seasons

There were many researches generally speaking, the thermal performance of traditional dwellings is better than that of modern dwellings [1, 3, 8, 10, 12]. As [1] study shows that the old houses can provide a year round comfortable environment; however the new houses are unable to provide indoor comfort in summer as well as winter. As Tiwari et al. (2004), there is a general perception that traditional architecture is better in terms of thermal environment than contemporary architecture. Rijal et al. (2006) in his study found that the residents of houses in Lomathang were highly satisfied with the thermal conditions of their houses in 3705 metre altitude in mountainous region. The findings show that people are well adapted to the thermal environment of traditional houses; as a result the adaptive neutral temperature is lower than the thermal comfort standard. This should be noticed to study the thermal comfort in vernacular architecture. 
In order to clarify air temperature, the results were analyzed by dividing traditional building in different seasons. Figure 4 shows the mean indoor and outdoor air temperatures of traditional buildings in all four seasons over one year period with $95 \%$ confidence interval. The most of traditional building indoor air temperature was lower than outdoor during daytime in the summer. The outdoor mean maximum air temperature ranges from 25 to $28^{\circ} \mathrm{C}$ whereas indoor mean maximum air temperatures range from 25 to $26^{\circ} \mathrm{C}$.

During winter, most of traditional buildings indoor air temperature was either same or higher than outdoor air temperatures. The outdoor mean maximum air temperature ranges from 11 to $14^{\circ} \mathrm{C}$ whereas indoor mean maximum air temperatures range from 12 to $15^{\circ} \mathrm{C}$ during morning and evening. The comfort temperature of Kathmandu is $15^{\circ} \mathrm{C}$ in winter and $26^{\circ} \mathrm{C}$ in summer (Rijal et al. 2010 \& Table 3). The result shows that the traditional residential building maintains comfort temperature in summer and within nearly comfort range in winter without any mechanically heated or cooled.

\subsection{Comparison of indoor and outdoor air temperature of traditional and modern building}

The research of [1] may be a good example to compare with the results of traditional and modern buildings of Kathmandu. Their study shows that the old houses can provide a year round comfortable environment; however the new houses are unable to provide indoor comfort in summer as well as winter. They write clay mixed with organic matter is the main building material. Their research shows that the indoor temperature is $35^{\circ} \mathrm{C}$ in modern house whereas it is only $28^{\circ} \mathrm{C}$ in traditional house in the old city in the same summer period in Ghadames, Libya. New buildings, therefore consume large amount of energy to maintain indoor thermal comfort.

In order to compare the thermal behavior of traditional and modern buildings of Kathmandu, air temperature were analysed by dividing in two different seasons of winter and summer. The figure 5 show normally during summer, mean indoor air temperature of traditional buildings were less than mean outdoor air temperature whereas mean indoor air temperature of modern buildings were higher than mean outdoor air temperature. The mean indoor air temperature during summer is $24.5^{\circ} \mathrm{C}, 25.5^{\circ} \mathrm{C}, 25.8^{\circ} \mathrm{C}, 26^{\circ} \mathrm{C}$ from ground to attic respectively when $26.3^{\circ} \mathrm{C}$ outdoor in traditional and $25^{\circ} \mathrm{C}, 26^{\circ} \mathrm{C}, 27^{\circ} \mathrm{C}, 27^{\circ} \mathrm{C}$ ground to attic respectively when nearly $25^{\circ} \mathrm{C}$ outdoor in modern building. The indoor mean air temperatures range from 24 to $26^{\circ} \mathrm{C}$ in traditional building when nearly $26^{\circ} \mathrm{C}$ outdoor and indoor mean air temperatures range from 25 to $27^{\circ} \mathrm{C}$ in modern building when nearly $25^{\circ} \mathrm{C}$ outdoor. This shows that traditional residential buildings were minimum 1 to $2^{\circ} \mathrm{C}$ cooler than modern residential buildings during summer.

Same way, during winter, in most of traditional residences mean indoor air temperature was either nearly same or little bit higher than mean outdoor air temperatures $\left(12.5^{\circ} \mathrm{C}\right)$. But in modern residences indoor air temperature was either nearly same or $1^{\circ} \mathrm{C}$ lower than mean outdoor air temperature $\left(11.5^{\circ} \mathrm{C}\right)$. This shows that traditional residential buildings were 1 to $2^{\circ} \mathrm{C}$ warmer than modern residential buildings during winter. 


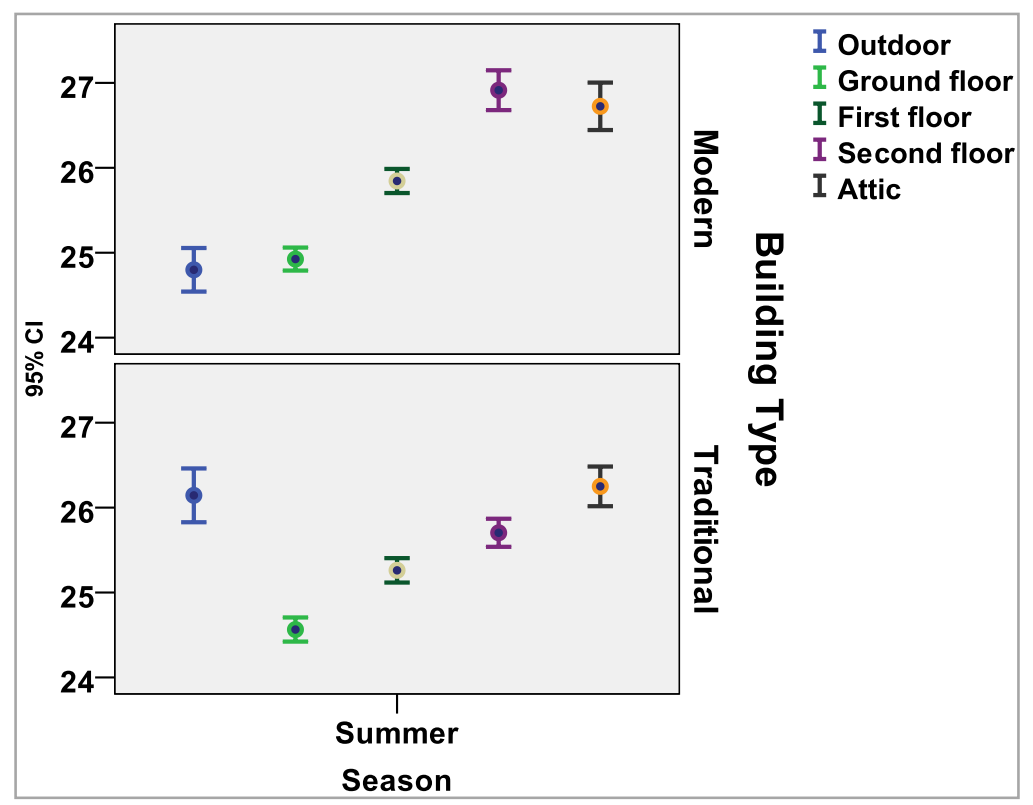

Figure 5: Comparison of indoor and outdoor air temperature in traditional and modern residential buildings during summer

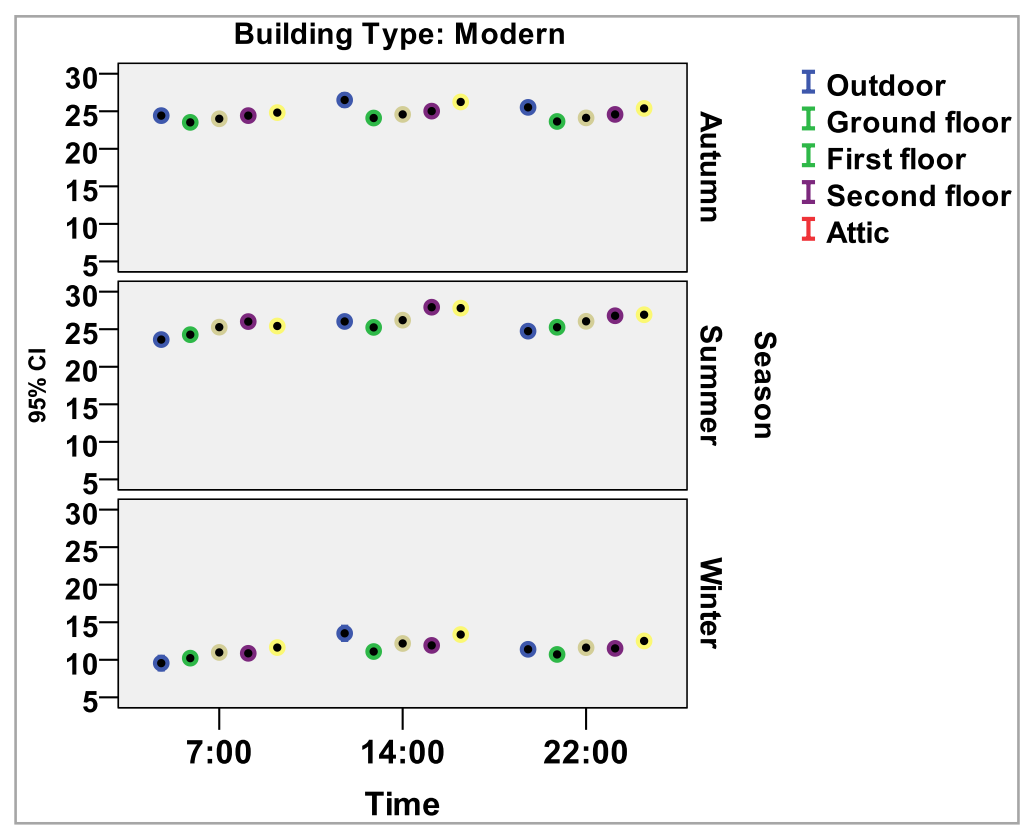

Figure 6: Mean Indoor and outdoor air temperature with 95\% confidence in modern residential buildings during different time and seasons

In order to know the thermal behavior of buildings, air temperature were analysed further by dividing the traditional and modern building in three different times a day in different seasons. Figures 4 and 6 show mean outdoor and indoor air temperature in the morning, day and evening of different seasons in traditional and modern buildings. During summer daytime, the indoor mean air temperatures range from 26 to $27^{\circ} \mathrm{C}$ in traditional building when nearly $29^{\circ} \mathrm{C}$ outdoor 
whereas indoor mean air temperatures range from 27 to $29^{\circ} \mathrm{C}$ in modern building when nearly $27^{\circ} \mathrm{C}$ outdoor. This shows that traditional residential buildings were minimum 1 to $2^{\circ} \mathrm{C}$ cooler than modern residential buildings during summer. Same way, during winter morning time, the indoor mean air temperatures range from 12 to $13^{\circ} \mathrm{C}$ in traditional building when nearly $9^{\circ} \mathrm{C}$ outdoor whereas indoor mean air temperatures range from 10 to $11^{\circ} \mathrm{C}$ in modern building when nearly $10^{\circ} \mathrm{C}$ outdoor. This shows that traditional residential buildings were minimum $2^{\circ} \mathrm{C}$ warmer than modern residential buildings during summer.

\subsection{Prediction of indoor air temperature by regression analysis}

One of the objectives of this paper is to develop new equation to predict the indoor thermal environment with the help of outdoor temperature. To predict the indoor air temperature of a residential building, the regression analysis of the indoor and outdoor air temperature was conducted with the help of SPSS software. Figures 7 and 8 show the examples of traditional and modern residential buildings. Table 4 shows the result of the linear regression analysis of the each floor of traditional and modern residential buildings. The equations for overall traditional and modern residential buildings are given below.

Traditional: $\quad T_{i}=0.8905 T_{o}+1.6125$

Modern: $\quad T_{i}=0.9392 T_{o}+1.3379$

Where:

$\mathrm{T}_{i}$ : Indoor air temperature $\left({ }^{\circ} \mathrm{C}\right), \mathrm{T}_{o}$ : Outdoor air temperature $\left({ }^{\circ} \mathrm{C}\right)$,

According to regression equation, when outdoor air temperature is $10^{\circ} \mathrm{C}$, the indoor air temperature in ground floor of traditional residential building is $12^{\circ} \mathrm{C}$ whereas the indoor air temperature in ground floor of modern residential building is nearly same $10^{\circ} \mathrm{C}$ (Table 2).

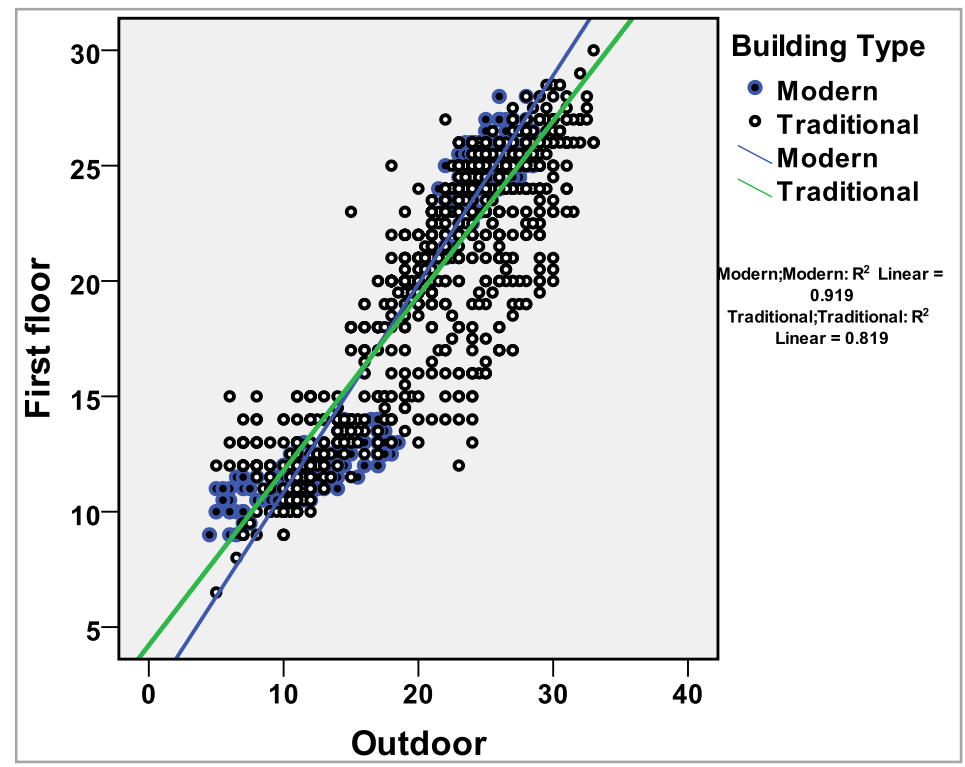

Figure 7: Regression analysis of the first floor air temperature and outdoor air temperature in traditional and modern residential buildings 


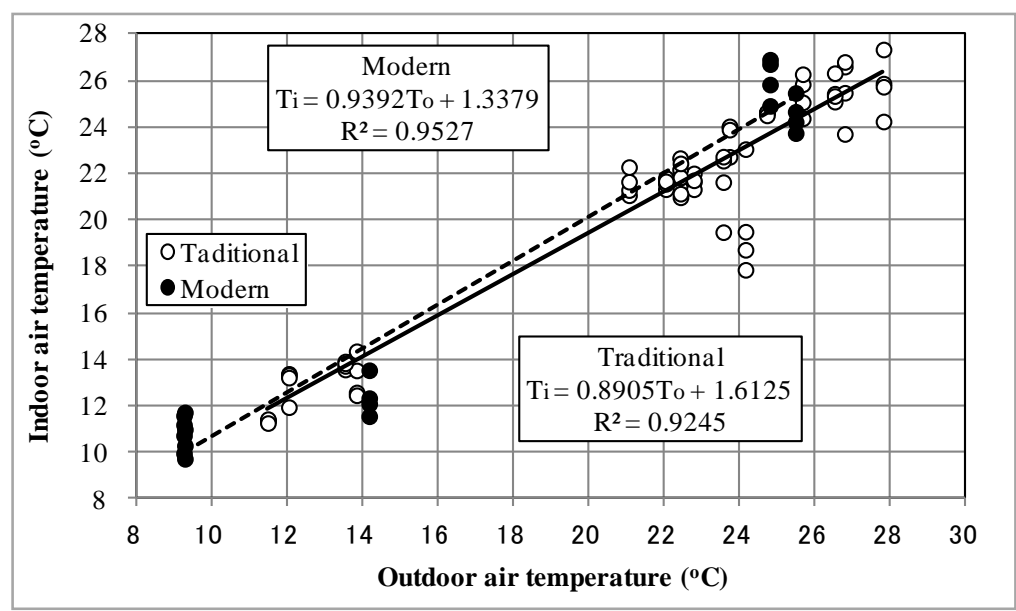

Figure 8: Relation between indoor and outdoor air temperature in traditional and modern residential building

Table 4: Regression equations of the indoor and outdoor air temperature

\begin{tabular}{|c|c|c|c|c|c|c|c|c|}
\hline Type & Floor & $\mathrm{n}$ & Equation & $\mathrm{R}_{2}$ & S.E. & $\mathrm{p}$ & $\begin{array}{c}\mathrm{T}_{\mathrm{p}} \\
\mathrm{Max} \\
\text { o C } \\
\end{array}$ & $\begin{array}{c}\mathrm{T}_{\mathrm{p}} \\
\mathrm{Min} \\
\mathrm{o} \mathrm{C}\end{array}$ \\
\hline & Ground & 1292 & $T_{i}=0.714 T_{o}+4.829$ & 0.82 & 0.009 & $<0.001$ & 24.8 & 12.0 \\
\hline \multirow[t]{4}{*}{ Traditional } & First & 1295 & $T_{i}=0.758 T_{o}+4.211$ & 0.82 & 0.010 & $<0.001$ & 25.4 & 11.8 \\
\hline & Second & 1276 & $T_{i}=0.806 T_{o}+3.610$ & 0.86 & 0.009 & $<0.001$ & 26.2 & 11.7 \\
\hline & Attic & 1295 & $T_{i}=0.885 T_{o}+2.301$ & 0.90 & 0.008 & $<0.001$ & 27.1 & 11.2 \\
\hline & Ground & 325 & $T_{i}=0.922 T_{o}+0.655$ & 0.93 & 0.014 & $<0.001$ & 26.5 & 9.9 \\
\hline \multirow[t]{3}{*}{ Modern } & First & 325 & $T_{i}=0.904 T_{o}+1.802$ & 0.92 & 0.015 & $<0.001$ & 27.1 & 10.8 \\
\hline & Second & 325 & $T_{i}=0.975 T_{o}+0.805$ & 0.92 & 0.016 & $<0.001$ & 28.1 & 10.6 \\
\hline & Attic & 325 & $T_{i}=0.937 T_{o}+2.165$ & 0.95 & 0.012 & $<0.001$ & 28.4 & 11.5 \\
\hline Traditional & All & 5158 & $T_{i}=0.890 T_{o}+1.612$ & 0.92 & & $<0.001$ & 26.5 & 10.5 \\
\hline Modern & All & 1300 & $T_{i}=0.939 T_{o}+1.338$ & 0.95 & & $<0.001$ & 27.6 & 10.7 \\
\hline
\end{tabular}

$\mathrm{T}_{i}$ : Indoor air temperature $\left({ }^{\circ} \mathrm{C}\right), \mathrm{T}_{o}$ : Outdoor air temperature $\left({ }^{\circ} \mathrm{C}\right), \mathrm{n}$ : number of sample, $\mathrm{p}$ : significant level of the regression coefficient, $\mathrm{T}_{\mathrm{p} \text { max }}$ : Predicted indoor air temperature when outdoor air temperature is $30^{\circ} \mathrm{C}, \mathrm{T}_{\mathrm{p} \text { min }}$ : Predicted indoor air temperature when outdoor air temperature is $10^{\circ} \mathrm{C}$

\section{Discussions}

This study conducted thermal measurements of the indoor and outdoor thermal environment of traditional as well as modern residential buildings in Kathmandu. There are many findings in this research to be discussed with other research finding before drawing conclusion. One of the research findings shows that traditional buildings are not out-of-date but it shows the positive aspects compared to modern buildings.

This study shows traditional building saves minimum $1-2^{\circ} \mathrm{C}$ temperature in both hot and cool seasons compared to modern building. But this also saves lot of energy. In the UK $10 \%$ of the heating energy used in winter is typically saved by lowering $1 \mathrm{~K}$ in the indoor temperature 
[9].This shows it saves energy for heating and cooling from 10-20\% in the budget of residents each year. This means these traditional building also saves minimum 10-20\% energy for either heating or cooling both in summer and winter than modern buildings of Kathmandu. It gives knowledge for saving energy and prepares an energy efficient design.

One of the objectives of this research is to help for conservation of energy efficient traditional residential building of Kathmandu. The implementation of Bye-law with conservation purposed shall be helpful to conserve traditional residential buildings of Kathmandu for future. The latest Bye-law (2064) of Kathmandu valley was developed for conservation purpose in chapter-4 of bye-laws of Bhaktapur. The traditional cultural residential zone is separated for the conservation purpose. The bye-laws of traditional cultural residential zone are better for the conservation purpose of traditional residential buildings among the five municipality of the valley. First of all, traditional cultural residential zone should be separated in all municipalities and in old towns of Kathmandu valley. Then these bye-laws shall be implemented with these findings as in Bhaktapur in all five municipalities and traditional settlement of Kathmandu valley for the conservation of traditional architecture.

During this study also show that the lower the room height better is the thermal performance. A large room requires more heating or cooling energy to create comfortable thermal condition than small room. A research finding shows volume of a room of traditional building is nearly two times less than that of a modern building. The volume of air of any space directly demands energy to create comfort thermal condition during extreme cold and hot season when extra energy is needed to control thermal condition. This is true in mechanically ventilated modern buildings than free running buildings. A big room requires more heating or cooling energy to create comfortable thermal condition than a small room. This is true in traditional bed room which demands less energy to heat and cool due to small size from the history and life style of people living in traditional building in the past. In the past, people use fire on a local stove (Makala) to keep warm themselves which keeps warm during morning and evening of cold winter. During summer, they open the single ventilated window to operate cooling in the room which create cool inside. This is possible only due to small bed room having low ceiling height and less surface area in a room.

\section{Conclusions and Recommendations}

The study focused on the measurement of thermal performance in field with monitoring thermal environment for one year. This paper has presented the data from thermal measurement in the field regarding the indoor and outdoor thermal environment of traditional residential buildings in Kathmandu. The research findings has identified traditional residential buildings has its own merit that it maintains thermal comfort. Compared to modern residential buildings, the traditional buildings have better thermal performance in winter and summer.

1. The field study identified traditional residential buildings maintain comfort temperature during summer season within 25 to $26^{\circ} \mathrm{C}$ which lies in comfort temperature as per Rijal and Nicol (Table 3).

2. Especially in the morning and evenings during winter season, indoor air temperature (12 to $\left.15^{\circ} \mathrm{C}\right)$ lies nearly comfort zone to comfort temperature $\left(13^{\circ} \mathrm{C} \& 15^{\circ} \mathrm{C}\right)$ for people in "free running" (not mechanically heated or cooled) building of Kathmandu as per Rijal and Nicol (Table 3). 
3. This support the Nicol theory of adaptive thermal comfort. This is the strongest point of this study with field work.

4. Indoor air temperatures were lower than outdoor air temperatures in summer whereas indoor air temperatures were higher than outdoor in winter in these traditional buildings.

5. Compare to modern residential buildings, the traditional buildings were 1 to $2{ }^{\circ} \mathrm{C}$ warmer in winter and 1 to $2^{\circ} \mathrm{C}$ cooler in summer.

6. It saves minimum 10-20\% energy for either heating or cooling both in summer and winter in traditional buildings than modern buildings of Kathmandu.

7. The linear regression equation is proposed to predict indoor air temperature by knowing the outdoor air temperature from weather forecast of meteorological department.

8. Thermal comfort is a basic requirement of any building. It saves energy to heat and cool in a building and impacts on the national economy too. This impact should be studied in new research.

9. How to reproduce more thermal comfortable and energy efficient residential building in Kathmandu is yet to be revealed in a broader perspective.

\section{References}

[1] Ahmad F., Khetrish E., Abughres S.M. (1985),Thermal analysis of the architecture of old and new houses at Ghadames ,Building and Environment 20 (1), pp.39-42.

[2] Ahmadreza F. (2012), Residents' perception of earthen dwellings in Iran, Urban Sustainable Development, pp.1-21.

[3] Algifri A.H., Bin Gadhi S.M., Nijaguna B.T. (1992), Thermal behavior of adobe and concrete houses in Yemen, Renewable Energy 2 (6), pp.597-602.

[4] Bajracharya S.B. (2013), A study on thermal performance of traditional residential buildings in Kathmandu valley, IOE, TU, Lalitpur, Nepal

[5] Bye-law of Kathmandu valley 2064 (2007), Government of Nepal, Kvtdc, Kathmandu, Nepal.

[6] Korn W. (1976), The traditional architecture of the Kathmandu valley, Ratna Pustak Bhandar, Kathmandu, Nepal.

[7] Madhavi I. (2010), Understanding the climate sensitive architecture of Marikal, a village in Telangana region in Andhra Pradesh, India, Building and Environment 45, pp.2709-2722.

[8] Meir I.A., Pearlmutter D. (1995), Assessing the climatic implications of lightweight housing in a peripheral arid region, Building and Environment 30(3), pp. 441-451.

[9] Nicol F., Jamy G.N., Sykes O., Humphreys M., Roaf S. \& Hancock M. (1994), A survey of thermal comfort in Pakistan, Oxford Brookes University, School of Architecture, UK.

[10] Rijal H.B., Yoshida H., Umemiya N. (2010), Seasonal and regional differences in neutral temperatures in Nepalese traditional vernacular houses, Building and Environment 45(12), pp. 2743-2753.

[11] Shrestha S.H. (1988), Nepalko Arthik Tatha Manabha Bhugol, Education Enterprises, Kathmandu, Nepal.

[12] Tiwari S.R., Hanaoka S., Rijal H.B., Hata S. and Yoshida H. (2004), Culture in Development Conservation of Vernacular Architecture, An Annual Journal of Architecture (Association of Students of Architecture, Nepal), Vaastu, Vol. 6, pp. 21-25, October. 